\title{
THE CONCEPTS OF BUSINESS MANAGEMENT IN THE OPINION OF ENTREPRENEURS
}

\author{
HANNA SOROKA-POTRZEBNA
}

University of Szczecin, Faculty of Management and Economics of Services, POLAND

e-mail: hanna.soroka@wzieu.pl

\begin{tabular}{l|l} 
RECEIVED & 6 November 2018 \\
ACCEPTED & 3 December 2018 \\
JEL & \\
CLASSIFICATION & G32, M11, M12
\end{tabular}

KEYWORDS management, concept, enterpreneurs, method

ABSTRACT The speed and unpredictability of changes occurring in the environment in which the enterprise operates, influence on the company and they must constantly change. Decisions made by managers have to be thought out and implemented in the right way. Helpful in adopting to these changes are the concepts of business management that support the activity. The number of concepts that entrepreneurs can use is very large. In the literature on the subject, many authors are describing each of them. The article focuses only on a few selected methods and is aimed to present the opinions of the entrepreneurs themselves. It allows to answer for example the question of which methods the surveyed enterprises use most often and which features of concepts have the most important meaning for entrepreneurs.

\section{Introduction}

Contemporary science of organization and management proposes different concepts and management methods that should be seen as supporting the organization's adaptive and/or anticipatory processes in relation to the changing environment (Czermiński et al., 2001, p. 500). 
Contemporary management concepts have certain common features, which include an orientation on reducing costs, increasing flexibility, developing relationships with clients, strengthening the competitive position. Managers must demonstrate not only the knowledge of different concepts, but also take an uneasy decision regarding the most suitable choice for a given company. This requires a thorough analysis, because the use of a specific concept can be a source of success or a failure of the company.

This article is an attempt to look closely at selected concepts and show the opinion of entrepreneurs. The research methods used to write an article are an analysis of the subject literature and own research carried out among small, medium and large enterprises.

\section{Literature review}

The number of concepts that managers can use is very large, they differ, among others, in terms of: nature, level of generality, complexity, ease of implementation, scope and pace of impact. Verified in business practice, concepts can become popular or become material for further improvement, concretization or integration with other, already proven tools and orientations (Lichtarski, 1999a, p. 254).

Due to the large number of concepts and methods described in the literature, only the most commonly used by entrepreneurs will be presented: outsourcing, controlling, CRM, benchmarking, lean management, TQM and BPR.

First concept, outsourcing, is defined as a venture of separating selected functions from the organizational structure and transfer them to other entities, outside the company (Trocki, 2001, p. 13). Other definition defines the concept as a two-elements, the first is to transfer a specific area to an external supplier, the second concerns longterm cooperation with an external enterprise (Kopczyński, 2010, p. 47).

This method enables the company to focus on key activities, and the rest to entrust to external entities. The following goals are distinguished by outsourcing (Gay, Essinger, 2002, pp. 16-17):

- reducing costs and controlling them,

- focusing on the core business of the company,

- acquiring new resources,

- distribution of operational risk,

- dealing with activities that were difficult or impossible for the company to control.

Second concept is controlling, which does not have a uniform definition, due to the application of the concept by enterprises with different organizational structures, as well as financial situation. The biggest influence on the concept had the American and German authors. According to American authors, controlling monitor the current results of the company and compare them with the objectives, as well as forecasting. On the other hand German authors define controlling as a comprehensive process, covering all the instruments that serve the management and control of the company's finances. For the purposes of this article, we will define controlling as an organization's control system, outcome oriented and implemented through planning, controlling and management (Koźmiński, Piotrowski, 2004, p. 221).

Customer Relationship Management (CRM) is a business strategy based on building customer loyalty towards an enterprise by developing mutually beneficial relationships (Deszczyński, Deszczyński, 2004, p. 173). S. Cook defines it as a strategic process of identifying the desired values of segments, micro-segments and individual clients on the basis of an integrated program of maximizing values for the client and organization by achieving the goal of gaining and retaining the client and increasing the profit of the enterprise (Cook, 2002). 
CRM assumes that it is more profitable to keep existing customers than to acquire new ones. That is why customer orientation should be a key element of the company's strategy.

The main goal of the next concept which is benchmarking, is to constantly compare the processes, models, products and services used with their counterparts in the market leaders. This allows company to improve and bring the company to a leadership position. The definition of the American Center of Productivity and Quality (APQC) says that benchmarking is a process of comparing your organization with the practice of functioning and results of the best organization in the world, and then use the acquired patterns in your organization (Kisperska-Moron, 2002). Other authors define the concept as:

a) seeking information on the most effective practices in the environment (Michalski, 2003, p. 170);

b) method of improving the organization (Mikuła, Ziębicki, 2001, p. 33);

c) the method of improving the company by imitating the best in the industry (Adamska, 2004, p. 57);

d) the method of comparing your own business solutions with model enterprises, improve your organization by learning from others and modeling on proven and effective solutions (Zakrzewska-Bielawska, 2012, p. 117).

In the literature, lean management, is defined in various ways. Some of the definitions emphasize the removal of losses and waste in the enterprise, for example according to J. Lichtarski the basic message of lean management is to remove excessive ballast, avoid all waste and achieve rationality in all areas of the company. It is a kind of philosophy of cool calculation, simplicity and savings (Lichtarski, 1999b, p. 16). Other definitions highlight the tools and techniques that are used. D. Mann defines lean management as a concept of covering discipline, everyday practices and tools necessary to create and maintain a continuous and intensive focus on processes (Mann, 2005, p. 5).

There are five most important principles of lean management (Hines, 2003, p. 8):

1. An indication of which activities bring value from the client's point of view.

2. Identifying activities along the value chain that are necessary to produce a product or service.

3. Development of a new value chain, without wastage in the form of disruptions, downtime, etc.

4. Respond to customer needs.

5. The removal of identified causes of waste, thanks to which the company strives for perfection.

In summary, lean management is a low-cost management that focuses on removing waste and increasing value-added activities. The company can do this by simplifying internal structures and procedures or applying appropriate techniques (Womack, Jones, Ross, 2001, p. 10).

Next concept, TQM is a method of comprehensive quality management, which is a philosophy focused on obtaining the highest possible quality in all processes and activities (Zakrzewska-Bielawska, 2012, p. 137). The use of TQM aims to achieve the following benefits for the company: increasing the company's credibility and increasing customer confidence, increasing sales, lowering costs, increase of employees' trust in the organization's management system.

The concept is based on the following principles (Zymonik, Zymonik 1994, p. 7):

1. Managing the company so that the customer is fully satisfied.

2. A strategic and systematic approach to continuous improvement of quality.

3. Every employee should have his client and internal supplier.

4. The main source of quality improvement is the creative work and deep knowledge gained through training. 
5. Creative work requires knowledge of methods and techniques of quality improvement.

6. An enterprise should be treated as a set of processes identified, analyzed and measured for improvement.

7. Actions should eliminate errors and the causes of defects should be systematically analyzed.

8. The concept should be supported by quality systems.

The message of the TQM concept is the statement that the quality of products is a derivative of the quality of its management system (including the quality of planning, organizing, motivating and controlling).

The last analyze concept is BPR (Business Process Reengineering). According to M. Hammer and J. Champy, creators of the concept, it is fundamental rethinking and radical redesign of processes in the company, leading to dramatic improvement in results achieved (such as costs, quality, service, speed) (Hammer, Champy 1996, p. 46). They also distinguish three types of organizations applying the concept, which include enterprises:

- struggling with serious problems, e.g. financial problems,

- threatened by big difficulties, e.g. after changing trends,

- having ambitious and aggressive management, ignoring noticeable problems.

A. Zakrzewska-Bielawska (2012, p. 118) mentions several characteristic features of the business process reengineering, which are:

a) fundamental rethinking of the company's organizational system from scratch;

b) radical redesign of the organization, at the strategic level, management system and organizational structure;

c) significant improvement in the results achieved, affecting the quantitative results of operations;

d) processes are considered a key dimension of the company's operations.

\section{Method}

The research were conducted using the CAWI method (Computer-Assisted Web Interview) among the 138 small, medium and large enterprises. The research was addressed to various enterprises in Poland and was carried out from May to August 2018. Entrepreneurs were asked five questions closed. Answers to the questions allow to gathering entrepreneurs' opinions on contemporary management concepts. In the research took part $54 \%$ medium-sized enterprises, $26 \%$ of large enterprises and $20 \%$ of small enterprises.

\section{Results}

Supplementing the theoretical considerations on selected concepts of business management is the presentation of the results of an online survey carried out in the period from May to August 2018 on a sample of 138 small, medium and large enterprises. Among the objectives of the study, it was indicated to answer the following questions:

1. Did you used concept of business management in your company?

2. What was the main advantage of choosen concept?

3. What was the main disadvantage of choosen concept?

4. What is, in your opinion, effectiveness of the selected methods?

5. Which concept, in your opinion, is the easiest and which is the most difficult?

On the first question, all entities indicated that they used in their operations a minimum one management concept. The most recommendations were received by controlling (42\%) and TQM $(38 \%)$, the next two methods were outsourcing and CRM (around 30\%). The enterprises rarely used the concept of Business Process Reengineering, 
only $6 \%$ of indications. Research has shown that the number of concepts used by the company increases with the size of the enterprise. The percentage share of answers to the question is presented in Figure 1.

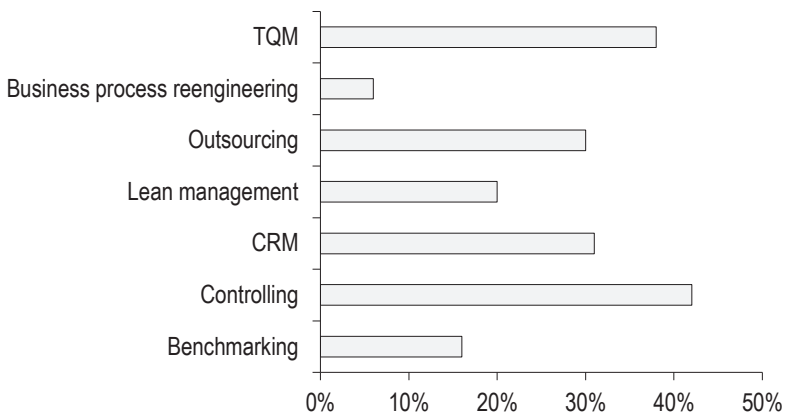

Figure 1. The use of individual management concepts in the operations of the surveyed enterprises

Source: own research.

The surveyed group of entrepreneurs was also asked to indicate the main advantages and disadvantages of the management concepts. Among the advantages were listed above all:

1. Raising your position on the market.

2. Improving the quality of products/services.

3. Reduction of operating costs.

4. Improvement of customer service.

5. Improvement of financial results.

Among the answer appear also: shortening the time of completing tasks, improvement of the personnel management process, increasing the satisfaction of owners or shareholders, concentration of activities on the most valuable clients.

And among the disadvantages, most often appeared:

1. Resistance of employees against changes that forces the concept.

2. Large implementation costs.

3. Too little knowledge of employees about the concept.

4. Short implementation time.

5. Cost-absorption.

Among the answer appear also: difficulties with adapting motivating systems to the concept, problems with adjusting employee evaluation systems, the qualifications of the employees involved in the implementation are too low, no funds for employing external experts, resistance of trade unions.

In the question about the effectiveness of the concepts, entrepreneurs could give a mark from 1 to 10 , where 1 was the most negative and 10 the most positive. The results of the research showed that the assessments of individual concepts differ only slightly. The best were the effectiveness of the re-engineering (8.0), followed by benchmarking and lean management (7.6), CRM (7.5), controlling (7.3), and the worst outsourcing and TQM (about 6.7). However, despite the best assessment of the effectiveness of re-engineering, in the last question 
this concept was rated as the most difficult of all analyzed. Second difficult concept by the companies was TQM. The easiest concepts in opinion of entrepreneurs were outsourcing and benchmarking. Other concepts were considered to be moderately difficult.

\section{Limitations}

Due to the limited volume of the article, it covers only a few selected concepts discussed in the literature.

\section{Conclusions}

Research among entrepreneurs has shown that the most important for them is maintaining the best position on the market, while distinguishing themselves by high quality and service level, without incurring high costs. However, there is a discrepancy between the concepts most commonly used and those best evaluated by entrepreneurs. This is due to the experience and limitations in the resources held by entrepreneurs, especially financial and personal resources. For example, re-engineering requires large implementation costs, hence not all enterprises are able to implement it, and often decide on a cheaper concept.

It is important that enterprises implement measures to eliminate the disadvantages of the chosen concepts. Crucial, among other things, is to train employees and strengthen positive attitudes towards changes that can occur. Attitudes should be grounded not only among management, but also among all employees. This requires an appropriate approach and awareness of the benefits of a particular concept for employees. It can also help to reduce stress among employees, that so effectively discourage them. Only the concept accepted and implemented at all levels of the company will bring the desired effect.

In addition, it is important for the literature to include items comparing different management concepts, as well as citing experiences and opinions of other entrepreneurs. This will help decision-makers in the enterprise to find the right method or concept of management easier and more accurately.

\section{References}

Adamska, M. (red.) (2004). Leksykon zarządzania. Warszawa: Difin.

Cook, S. (2002). Customer Care Excellence. How to create an effective customer Focus. London: Kogan Page Ltd.

Czermiński, A., Czerska, M., Nogalski, B., Rutka, R., Apanowicz, J. (2001). Zarządzanie organizacjami. Toruń: Towarzystwo Naukowe Organizacji i Kierownictwa „Dom Organizatora”.

Deszczyński, B., Deszczyński, P. (2004). Customer Relationship Management konsekwencją globalizacji. Zeszyty Naukowe Akademii Ekonomicznej, 44, 168-192.

Gay, C.L., Essinger, J. (2002). Outsourcing strategiczny. Kraków: Oficyna Ekonomiczna.

Hines, P. (2003). Kierunek - organizacja LEAN. Gdańsk: Wydawnictwo LeanQ Centrum.

Kisperska-Moroń, D. (2002). Benchmarking jako narzędzie zarządzania logistycznego. Katowice: Wydawnictwo Akademii Ekonomicznej. Kopczyński, T. (2010). Outsourcing w zarządzaniu przedsiębiorstwem. Warszawa: PWE.

Koźmiński, A.K., Piotrowski W. (2004). Zarządzanie. Teoria i praktyka. Warszawa: Wydawnictwo Naukowe PWN.

Lichtarski, J. (1999a). Podstawy nauki o przedsiębiorstwie. Wrocław: Wyd. Akademii Ekonomicznej.

Lichtarski, J. (1999b). Współczesne koncepcje zarządzania przedsiębiorstwem - istota, relacje, problemy stosowania. Przegląd Organizacji, 11, 13-18.

Mann, D. (2005). Droga Toyoty. 14 zasad wiodącej firmy produkcyjnej świata. Warszawa: MT Biznes.

Michalski, E. (2003). Zarządzanie przedsiębiorstwem. Podręcznik akademicki. Warszawa: PWE. 
Mikuła, B., Ziębicki, B. (2001). Metodologiczne aspekty procesów organizacyjnego uczenia się. Problemy Jakości, 3, 30-34. Trocki, M. (2001). Outsourcing. Metoda restrukturyzacji działalności gospodarczej. Warszawa: PWE.

Womack, J., Jones, D., Ross, D. (2001). The machine that change the world: the story of lean production. Harper Colins. Zakrzewska-Bielawska, A. (red.) (2012). Podstawy zarządzania. Warszawa: Oficyna a Wolters Kluwer business.

Zymonik, Z., Zymonik, J. (1994). Kompleksowe zarządzanie jakością. Nowator, 7.

Cite this anticle aS: Soroka-Potrzebna, H. (2018). The concepts of business management in the opinion of entrepreneurs. European Journal of Service Management, 4 (28/1), 297-303. DOI: 10.18276/ejsm.2018.28/1-37. 